\title{
The SFL genre-based approach to writing in EFL contexts
}

Akiko Nagao (D)

\author{
Correspondence: nagao@world. \\ ryukoku.ac.jp \\ Ryukoku University, 67 \\ Tsukamoto-cho, Fukakusa \\ Fushimi-ku, Kyoto 612-8577, Japan
}

\begin{abstract}
This research investigates the changes in English as a Foreign Language (EFL) learners' psychological attributes in relation to awareness of the lexicogrammatical features and generic structures of a discussion genre essay. This was achieved by implementing a genre-based approach to text-based writing lessons during a 15week course. The following lesson procedure was implemented: stage (1): modeling and deconstruction of a text, stage (2): writing of target texts, stage (3): genre analysis of peers' essays, and stage (4): writing of an analysis reflection. The results indicated specific improvements in genre-based writing, particularly among lowproficiency English learners. Results suggest that their understanding of "interpersonal meaning" such as modal verbs improved. Improvements in the use of modal auxiliaries were also noted, in that the word "should" did not appear in prewriting texts; however, the frequency improved in post-writing texts, especially in the final paragraph, which comprised the writers' opinions and suggestions.
\end{abstract}

Keywords: English as a foreign/ second language (EFL/ ESL), English for speakers of other languages (ESOL), Linguistics, Teacher and learner variables

\section{Introduction}

Systematic functional linguistics (SFL) is a theoretical approach that analyzes the relationship between social contexts and linguistic aspects (Halliday \& Matthiessen, 2014). The core concepts of SFL are language as functional and language as meaning-making (Halliday, 1978). The first concept refers to language attributes: understanding a language means understanding how people use the language in context and how it is structured for use (Halliday \& Matthiessen, 2014). According to the second concept, language as meaning-making, speakers and writers have a systematic choice in a particular context (Halliday \& Matthiessen, 2014). When writing an email message to a friend, person A chooses particular lexicogrammatical functions, which are different from those used when the same person writes an email message to inquire about a job. Thus, the context of a situation is related to the meaning-making choice.

The common focused features of English as a Foreign Language (EFL) learning in high school classrooms in Japan among 2134 high school teachers in 2015 were reading texts aloud, practicing pronunciation, and explaining the uses of lexicogrammar (Benesse Educational Research and Development Institute, 2016). Having learners write sentences or essays about their opinions and summarizing textbook contents were less focused during EFL lessons at Japanese high schools (Benesse Educational

(c) The Author(s). 2019 Open Access This article is distributed under the terms of the Creative Commons Attribution 4.0 International License (http://creativecommons.org/licenses/by/4.0/), which permits unrestricted use, distribution, and reproduction in any medium, provided you give appropriate credit to the original author(s) and the source, provide a link to the Creative Commons license, and indicate if changes were made. 
Research and Development Institute, 2016). One study revealed how 140 EFL learners at a private university in Japan considered the importance of learning English: 28\% of them considered improving listening skills to be important, while $11 \%$ of them agreed that learning how to write texts in English was important (Yamashita, 2012). Sugiura (2017) explores the changes of 37 Japanese university students' understanding of their English learning styles from when they were high school students to when they became university students through an analysis of narrative frameworks. Many of them learned lexicogrammar of English using textbooks provided in a teacher-dominated setting in high school, while they tended to be taught mostly through practicing verbal communication while at university (Sugiura, 2017). Their narratives, however, said far less about the ways that they learned how to write in English. Murakoshi (2015) reported that writing practices and activities in classrooms tended to consist of opportunities for EFL learners to practice writing sentences and paragraphs in order to establish linguistic knowledge. The aim of this paper is (1) to introduce an SFL-genre-based approach to teaching methodology that reckons with the changes in EFL learners' awareness of target genre in particular learning contexts, and (2) to explore the idea that learning how to write consists of more than creating a cognitive network in terms of linguistic knowledge as it is processed by learners' brains. Language as functional and language as meaning-making purposes is applicable or not within the EFL classroom contexts.

\section{Literature review}

\section{Systematic functional linguistics and genre}

In SFL theory, the relational concept of linking the context of a situation with linguistic choices is called register. Register has three features; Field, Tenor, and Mode, which are related to the following metafunctions (see Table 1; Halliday \& Matthiessen, 2014; Martin \& Rose, 2008). The Field facilitates understanding of how and when people use particular lexicogrammatical features such as mental verbs and elements of cohesion; these are ideational metafunctions that allow us to understand what is occurring in the text. The Tenor facilitates understanding of how and when the writer chooses particular modalities and appraisal systems; this interpersonal metafunction helps us to understand the relationship between writers and readers. Finally, the Mode facilitates analysis and understanding of the Theme and Rheme as well as cohesive devices; this textual metafunction allows us to understand how the text is organized.

Table 1 Context of the Situation and Linguistic Features

\begin{tabular}{|c|c|c|c|}
\hline \multirow{2}{*}{$\begin{array}{l}\text { Layers } \\
\text { Context }\end{array}$} & \multicolumn{3}{|l|}{ Categories } \\
\hline & Field & Tenor & Mode \\
\hline Register variables & $\begin{array}{l}\text { What is going on in } \\
\text { the text? }\end{array}$ & $\begin{array}{l}\text { What is the relationship between } \\
\text { writers and readers? }\end{array}$ & $\begin{array}{l}\text { How is the text organized, } \\
\text { in spoken text or written } \\
\text { text? }\end{array}$ \\
\hline $\begin{array}{l}\text { Linguistic } \\
\text { realization in } \\
\text { metafunction }\end{array}$ & $\begin{array}{l}\text { Ideational meaning: } \\
\text { when, how, who, } \\
\text { where, and what }\end{array}$ & $\begin{array}{l}\text { Interpersonal learning: politeness, } \\
\text { modality, and evaluative terms; } \\
\text { attitudes, positions, and social roles }\end{array}$ & $\begin{array}{l}\text { Textual meaning: Theme } \\
\text { and Rheme as well as new } \\
\text { and old information. }\end{array}$ \\
\hline $\begin{array}{l}\text { Lexicogrammatical } \\
\text { features }\end{array}$ & $\begin{array}{l}\text { Vocabulary, } \\
\text { grammar, and tense }\end{array}$ & Mood, modalities & Theme; this, it, and that \\
\hline
\end{tabular}

Note. Information in the table is based on Halliday and Matthiessen (2014) 
Genre in SFL represents the systems of social processes that constitute a culture (Martin \& White, 2005). Rose (2013, p. 209) claimed that the approach of genre has been influenced by features: "Halliday's (1975) theory of language regarding the social semiotic process, Bernstein's (1990) sociological theory, and a series of large-scale action research projects in literacy education (Martin, 1999; Rose, 2008)." Bhatia (2004) summarized some common features of genre studies: Genre refers to language in a stylized communicative setting in order to allow speakers and writers to express a definitive set of communicative goals of a disciplinary or social institution. Genre gives us stable structural forms, including the use of lexicogrammatical and semiotic resources (Bhatia, 2004).

Genre was defined differently in English for specific purposes (ESP) by Swales (1990, p. 58), who defined the key concepts in ESP as "discourse community, communicative purpose, and genre." Here, genre is a category of communicative events holding some communicative purpose. In other words, genres in ESP are understood as communicative tools in the social context of the discourse community, and understanding the functions of generic structure and lexicogrammar help us to understand the communicative goals (Fakhruddin \& Hassan, 2015). In sum, genres in ESP are forms of communicative action.

Martin (1984, p. 25) stated that genre in SFL is "goal-oriented and has a social activity purpose:" writers and speakers who use the genre engage in these activities as "members of their culture." Eggins (2004) proposed that each genre text has a different cultural purpose based on its generic structure and realizational pattern. Realization of the relationship between (1) social purposes and (2) contexts as specific linguistic interactions is the key concept in SFL (Fakhruddin \& Hassan, 2015). Understanding social purposes and contexts allows us to discern the meaning of the language and specific social actions (Fakhruddin \& Hassan, 2015).

In this study, genre is defined as types of written text that help us to understand the relationship between the text's social purpose and structure, which influence writers' linguistic actions.

\section{Previous research on the SFL genre (text)-based approach of writing in EFL contexts}

Most current research on the genre-based approach (GBA) and SFL have implied improvement in learners' generic structural awareness rather than in their lexicogrammatical meaning-making choices. Chen and Su (2012) and Feez (2002) emphasized that the use of GBA with the teaching-learning cycle (TLC) has five stages: (1) setting of the context, (2) modeling, (3) joint construction, (4) independent construction, and (5) comparison. The GBA and TLC were effective in terms of learners' summarization ability, especially their organization of the narrative genre text's structure rather than vocabulary and language use (Chen \& Su, 2012; Feez, 1998; Feez, 2002). Carstens (2009) investigated the effectiveness of using GBA with SFL grammar as the theoretical framework for teaching academic writing to second-year undergraduate students of Humanities at the University of Pretoria. Although it is challenging for many tertiary-level learners to acquire specific knowledge and skills to write particular academic genre texts, genre-based writing has the capability to enhance their writing abilities. However, very little empirical research has been conducted in this area. Carstens' (2009) study 
applied a mixed methods design using genre analysis, discourse analysis, survey of writing tasks, and pre- and posttest essay ratings. The results indicated that the following genre types were required to write academic essays: argumentation, discussion, explanation, and description genre texts (Carstens, 2009). Despite limited research, studies on EFL writing based on SFL-GBA teaching and learning have found that learners improved their understanding of the logico-semantic relationship. In Srinon's (2011) study, learners' use of resources to construct a logico-semantic relationship increased; that is, the frequency of using single-clause sentences reduced, and sentences including hypotaxis and parataxis increased.

SFL-GBA teaching usually involves the TLC, which is a systematic approach guiding EFL learners on how to interrelate lexicogrammatical features as well as functions and writers' shared experiences in the context when they write. The original TLC has three stages: deconstruction of the target genre's written texts, joint construction, and independent construction (Feez, 1998; Feez, 2002). Many studies on SFL-GBA writing have reported the benefits of applying this TLC to explore the degree to which genre-based teaching allows learners to gain genre awareness and improve writing quality when they write argumentative essays (Tsou \& Lin, 2013). However, in their study, Tsou and Lin (2013) found that the control group learners' understanding of genre awareness did not improve significantly. The concept of TLC allows EFL teachers and instructors to utilize the scaffolding strategy. Syarifah and Gunawan (2015) observed improvement in six EFL learners' writing performance of a discussion genre text; in particular, the social function, schematic structure, and language features improved because of the SFL-GBA writing lesson. Thus, their results showed that scaffolding was embedded in the TLC. Viriya and Wasanasomsithi (2017) used the genre approach to writing lessons while using the TLC (Feez, 2002) for a 12-week period. The target for these learners was to produce a genre text that was informative and persuasive. However, there was little improvement in the learners' awareness of the reader-writer relationship and what they should write about. Viriya and Wasanasomsithi (2017) concluded that these learners' discourse community was within the classroom, and therefore they knew that their audience, that is, the reader of the text, would only be the instructor. Therefore, awareness of the reader-writer relationship did not improve significantly in the post-task. In SFL theory, the concept of Tenor indicates the degree of formality, power, and effect that usually influence interpersonal choices in terms of linguistics systems (Halliday, 1978, p. 143). However, this idea might have been omitted in the learning classroom context in Viriya and Wasanasomsithi's (2017) study.

Finally, although the majority of research on GBA teaching and learning has found that the SFL-GBA pedagogy is useful for EFL learners, most studies have demonstrated little understanding regarding which features of the approach are useful. Many studies have focused on learners' generic awareness improvement but not on the changes in teachers' understanding of how to teach writing using SFL and GBA. Shi (2015) applied a qualitative case study method by analyzing interviews, classroom observations, and students' writing data. These students' target genre was a discussion text. The authors found that through the workshop training, teachers' (1) curricular knowledge, (2) subject matter content knowledge, and (3) pedagogical content knowledge about the target genre was improved. These teachers realized that their former approach of teaching how to write the target genre text was too general, with insufficient details about the 
generic structure. They found that genre pedagogy can provide learners with step-by-step instructions on how to write the target text. The teachers' content knowledge of the target genre text allowed them to gain subject matter content knowledge and curriculum knowledge. These teachers believed that the modeling stage of the TLC in particular, allowed students to gain awareness of the textual features within target genre texts.

\section{SFL-GBA writing research on EFL contexts in Japan}

Contemporary genre research into the Japanese language has been conducted since the 1970s, focusing in particular on Japanese discourses. Therefore, the study of genre in Japanese language using the concept of SFL as a framework is now a well-established field of research (Thomson, de Silva Joyce, \& Sano, 2017). However, EFL research on writing using the concept of SFL in the classroom context in Japan has not yet been fully established. The concept of SFL has recently been appreciated in EFL-based countries, and its theory and practicums have been integrated into English classes. Tatsuki (2006) analyzed the relationship between generic structures and lexicogrammatical features, and introduced the concept of SFL theory and practical application using genre texts with real situations.

Cornelius and Cotsworth (2015) clearly explained possibilities for applying SFL-GBA teaching in classroom learning contexts. Novice writers may find the conventionalities of EFL academic writing problematic, especially for lower English proficiency learners in the EFL classroom contexts of Japanese universities (Cornelius \& Cotsworth, 2015). Cornelius and Cotsworth found that the Australian School of Genre approach (i.e., the TLC) can be an alternative solution that allows EFL learners to understand how the text is composed using a holistic approach and also allows EFL teachers to teach by explaining the target genre texts' purpose, generic structures, and linguistic markers. Moreover, through this GBA of learning, learners have the responsibility for the output and their interaction (Cornelius \& Cotsworth, 2015). During EFL learning in Japan, many learners might think that the grammar function, vocabulary, and meaning of a genre are separate aspects; however, the core concept of SFL and GBA is that "grammar and vocabulary are related to the meaning of the genre and not viewed as separate aspects" (Cornelius \& Cotsworth, 2015, p. 19). It is important for EFL learners to become familiar with the text's purpose, structure, and language features by engaging in tasks with sample texts that allow them to recognize the particular genre (Cornelius \& Cotsworth, 2015). The GBA method of learning writing benefits novice EFL learners in Japan by ensuring the above (Cornelius \& Cotsworth, 2015). In addition, EFL learners need to be aware of the different social contexts when they engage in writing; however, it can be challenging for EFL learners to understand these differences (Badger \& White, 2000), as they affect the choice of appropriate lexicogrammar and generic structure that are suited to the social context. For example, writing factual description texts and writing option essays use different lexicogrammatical features such as modalities. Learning to write using the GBA can solve the above issue.

Watanabe (2016) analyzed 50 writing tasks given in university entrance examinations in Japan. Learning of English in junior and senior high schools in Japan is highly entrance-examination driven; in other words, learners at high schools are familiar with 
how to write these particular genre texts through classroom lessons, although they do not have sufficient exposure to other genres. Thirty EFL learners in Japan, who were in two different proficiency groups, participated in the GBA with the SFL framework; these learners' understanding of tone, register, and audience awareness were improved in the post-writing task (Yasuda, 2012).

Yasuda (2015) used SFL as the research framework to investigate the changes in EFL learners' generic and language features. This author identified changes in learners' understanding of interpersonal and textual meanings through SFL-informed genre analysis tasks. Yasuda (2015) concluded that genre-specific language learning with an SFL framework can enhance writers' awareness of ideational, interpersonal, and textual meanings in summary writing. One limitation of Yasuda's (2015) study, however, was the focus on learners with different English proficiency levels. Therefore, this study attempts to examine two groups: learners with higher and lower English proficiency.

\section{Contribution of this study}

The efficacy of the approach of genre-based pedagogy (GBP) in teaching EFL academic writing and in learners' learning of specific genres has not been well discussed in theoretical and anecdotal research. Few empirical studies have been conducted to assess whether the GBP approach benefits learners in their learning of a target genre. The use of the GBA with the SFL framework is a relatively new method of teaching English language writing to undergraduate university students in Japan. Therefore, this study was conducted to answer the following research questions:

RQ 1 How does the learners' awareness of the target genre text change in terms of their use of generic structures and appropriate lexicogrammatical choice in the General English for Academic Purposes writing class?

RQ 2 How do learners understand words that have interpersonal meanings, and how do they use modal auxiliaries in writing a discussion genre essay?

\section{Methods}

\section{Participants}

The study participants comprised 27 first-year university students who belonged to two different classrooms: 13 EFL learners (female: $n=9$, male: $n=4$ ) in the higher English proficiency class, which is equivalent to IELTS 5.5 (upper-intermediate level) and 14 learners (female: $n=11$, male: $n=3$ ) in the lower English proficiency group, which was equivalent to IELTS 4.0 (pre-intermediate level). The common academic goals in their discourse community were (1) to participate in studies abroad, a university requirement for graduation and (2) to improve their meaning-making lexicogrammatical choices when writing academic essays such as discussion genre essays. Their English proficiency and understanding of a variety of genre texts were very limited; most participants with lower English proficiency had difficulty comprehending academic writing papers with several paragraphs. All participants were informed of the research purpose and asked to fill in their informed consent form at an early stage in the semester, before 
they participated in this research. The research purpose and preservation of participant anonymity were explained to them whenever they participated in tasks.

\section{Procedures}

The following theories were applied as the framework in a 15-week semester sequence of genre-based EFL instruction. The particular concept from Halliday and Matthiessen (2014) and Martin and Rose (2008) for theoretical framework has been applied in this reaching. The contents of tasks and activities include submaterials for each GBA lessons were applied from Carstens (2009), Chen and Su (2012), NSW Department of School Education (1989). Moreover, Feez's (2002) TLC was also applied three times during the 15-week lesson. The target genre text for the first cycle within 4 weeks was an "exposition (hortatory) genre text," that for the second cycle was an "exposition (analytical) genre text," and the third target genre was a "discussion genre text" during the last cycle. The fundamental lesson procedure for the TLC was as follows: (1) modeling and deconstructing a text, (2) writing the target text, (3) analyzing the genres of peers' essays, and (4) writing the analysis reflection sheet.

In stage (1), learners had an opportunity to analyze the structure and language features of the modeling text. After decoding the model text, learners were asked to find a text similar to the target genre text online and then analyze it. That is, the learners were provided a great deal of input and time to expose themselves to the target genre in order to allow them to see how the purpose of the genre text is conveyed through the text organization and language features (Cornelius \& Cotsworth, 2015; Hammond et al., 1992).

In stage (2), learners completed a timed writing exercise within 50 to $60 \mathrm{~min}$. In stage (3), they analyzed the target genre essay's generic structure and language features using peers' essays; questions for the analysis were taken from Shi (2015). First, a move analysis was conducted for the first, second, and third paragraphs of the discussion type essay to assess learners' understanding of the generic structure (see Fig. 1). Second, learners identified the frequency of the use of personal nouns and action verbs to assess the writers' appropriate lexicogrammatical field choices. They then analyzed the frequency of word modalities, such as modal verbs and adverbs, to evaluate the appropriate tenor choices. Next, the frequency of word construct conjunctions, that is, appropriate mode choices, was assessed. The final task was to reflect on the learners' genre analysis results.

\section{Data sources}

In phase 1, to elicit in-depth qualitative insights to answer RQ 1, 21 learners conducted genre analysis reflection of written texts (higher-level: $n=9$, lower-level: $n=12$ ). Six students did not complete this task, as they were absent. In stage (4) of Feez's (2002) TLC, immediately after the learners completed the segment analysis of their peers' essays, they completed the reflection writing task using the analysis reflecting sheet, which took approximately $40 \mathrm{~min}$; this was conducted at the end of the semester. Learners were given open-ended reflection questions on which they needed to reflect based on their understanding of the target genre text. The questions were based on Nagao (2017), Shi (2015, p. 263), and Yasuda (2015). The questions for the analysis 


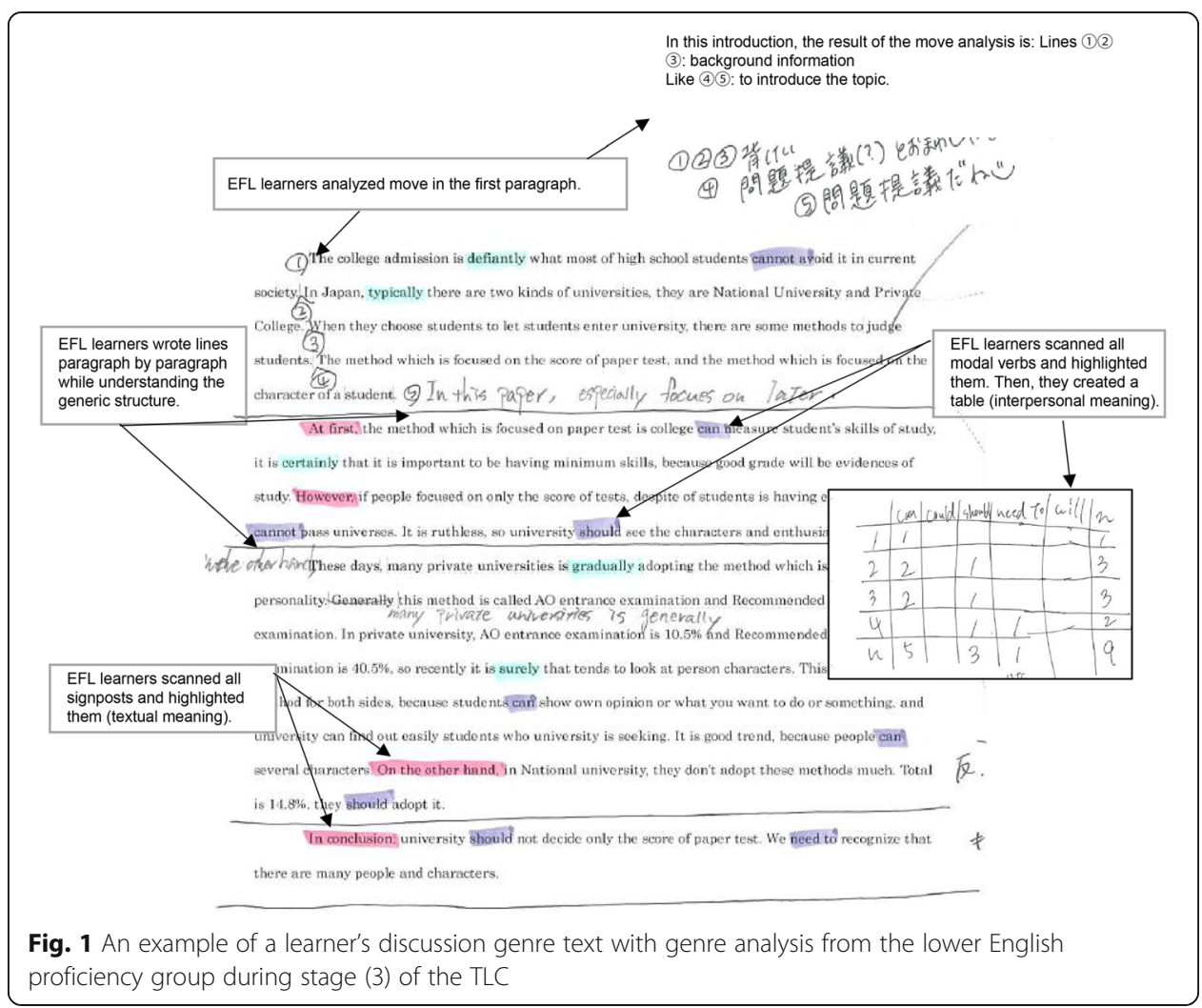

sheets are follows: Q1: Please summarize the features that provided new information and knowledge through this genre analysis of a peer's discussion essay and Q2: Please summarize the result of the genre analysis. Discuss why the results were different from yours.

In Phase 2, discussion type essays that learners produced at the beginning and end of the semester as a non-instructional and instructional writing task, respectively, were explored in order to answer RQ 2: How do learners understand words that have interpersonal meanings, and how do they use modal auxiliaries in writing a discussion genre essay? The writing topics were "Does the individual have the right to privacy?" for the pre-writing task and "Should academic achievement be a primary consideration for college admission?" for the post-writing task. Twenty-one learners participated in these tasks (higher-level: $\mathrm{n}=9$, lower-level: $\mathrm{n}=12$ ).

The attribution discussion genre essay was adopted from the NSW Department of School Education's (1989) Metropolitan East Disadvantaged Schools Program and Srinon (2011). The function of the discussion genre essay is for writers to present information and explain arguments from both sides (for and against; pros and cons) of the topic and issue. Based on these evidential explanations, writers introduced their own opinions and recommendations in the final paragraph. During the post-instructional writing task, learners had the opportunity to consider who could be an appropriate audience for the target genre texts. The generic (schematic) structure of the discussion genre essay comprises four paragraphs: introduce the topic and issue, write arguments for (or against), write arguments against (or for), and write recommendations and the writer's opinion. The language features of the discussion genre essay are: some 
vocabulary items embedded in the (1) ideational meaning (Field) such as human and non-human participants and mental and action verbs, (2) interpersonal meaning (Tenor) such as modal verbs and adverbs, and (3) textual meaning (Mode) such as construct conjunctions.

\section{Analyses}

Phase 1-12 criteria from Burns, Joyce, and Gollin (1996) were applied to assess the self-reflection content written to explore how learners used generic structure and lexicogrammar in their essays (see Table 2). All 318 sentences (higher-level: $n=172$, lower-level: $n=146$ ) of the learners' self-reflection written texts were coded with the 12 criteria.

Phase 2-Pre- and post-timed writing: This study focuses on modal-makers based on the SFL framework (Halliday \& Matthiessen, 2014), which is classified into two different types: modality-type and modal semantics. The modality type is categorized into verbal modality and nonverbal modality. In verbal modality, modal auxiliaries such as can, may, and could, semi-modal verbs such as have to and ought to, and lexical verbs such as allow and oblige are listed. This study analyzes the frequency of modal auxiliaries. According to Halliday and Matthiessen (2014) and Halliday and Hasan (1989), modal verbs have different degrees of certainty, probability, or obligation, and choosing appropriate modal verbs is essential to realizing the interpersonal functions and expressing the social roles of writers and readers. Moreover, writers and speakers use these modal verbs to reflect their attitudes such as judgment (e.g., You must know a lot of things now.) and possibilities (e.g., I can participate in the meeting tomorrow.) toward a situation or event, which are called values. These values are classified as high, median, and low (Table 3). For example, one hypothesis is that a large number of modal

Table 2 Assessment Criteria

\begin{tabular}{|c|c|c|}
\hline Categories & Sub-categories & Assessment Criteria \\
\hline \multirow[t]{2}{*}{$\begin{array}{l}1 \text { Generic } \\
\text { Structure }\end{array}$} & $\begin{array}{l}\text { Identifies sociocultural purpose of } \\
\text { genre }\end{array}$ & (1) To identify the purpose of the discussion essay \\
\hline & $\begin{array}{l}\text { Identifies motivation of genre as } \\
\text { interpersonal or pragmatic }\end{array}$ & $\begin{array}{l}\text { (2) To describe the structure of the target genre: 1) } \\
\text { Issue, 2) Argument for, 3) Argument against, and 4) } \\
\text { Conclusion }\end{array}$ \\
\hline \multirow{10}{*}{$\begin{array}{l}2 \\
\text { Lexicogrammar }\end{array}$} & \multirow{4}{*}{$\begin{array}{l}\text { Makes appropriate } \\
\text { lexicogrammatical ideational } \\
\text { meaning choices (Field) }\end{array}$} & (3) To explain general personal nouns \\
\hline & & (4) To write about the uses of abstract nouns \\
\hline & & (5) To write about the uses of action verbs \\
\hline & & (6) To write about the uses of "verbal verbs" \\
\hline & \multirow{3}{*}{$\begin{array}{l}\text { Makes appropriate interpersonal } \\
\text { meaning choices (Tenor) }\end{array}$} & (7) To write about modalities \\
\hline & & (8) To write about modality + adverbs \\
\hline & & $\begin{array}{l}\text { (9) To write these fixed phrases to express the writer's } \\
\text { opinion/modality: It is possible that, I guess that, or It is } \\
\text { certain that }\end{array}$ \\
\hline & \multirow{3}{*}{$\begin{array}{l}\text { Makes appropriate textual meaning } \\
\text { choices (Mode) }\end{array}$} & (10) To explain construct conjunctions and signposts \\
\hline & & $\begin{array}{l}\text { (11) To explain demonstrative pronouns such as that } \\
\text { and this }\end{array}$ \\
\hline & & $\begin{array}{l}\text { (12) To use appropriate thematic ties and referential } \\
\text { links to extend genre }\end{array}$ \\
\hline
\end{tabular}


Table 3 Different Value Degrees of Modal Verbs

\begin{tabular}{ll}
\hline Values & Modal verbs \\
\hline High & must, should, ought to, need to, has to, is to \\
Median & will, would, shall \\
Low & may, might, can, could \\
\hline
\end{tabular}

Note. The information is based on Halliday (1994, p. 362) and Tatsuki (2006, p. 76)

auxiliaries with high values-must, should, ought to, need to, has to, or is to-will possibly appear in the final paragraph of the discussion genre text for writers to express their strong opinions. The other hypothesis is that the modal auxiliary, will, may appear in the introduction paragraph of the discussion genre essay. EFL learners from the 15 -week lesson used in this research were taught the different value degrees of modal verbs (see Table 3 ) during stage (1) of the TLC for modeling and deconstructing a text. First, the results of the statistical description were analyzed using the UAM corpus tool, which facilitates linguistic annotation of text corpora. Second, the frequencies of modal auxiliaries such as can, may, and could were identified for each paragraph of the learners' pre- and post-writing essays (Shi, 2015). Before writing the post-essay, learners were taught the precise classification of the values of modal auxiliaries. Dates for the collection of the essays (data) are provided in Table 4.

\section{Results}

Phase 1: genre analysis of peers' reflection essay results

To answer RQ 1, the learners' reflections on the results of the genre analysis, primarily regarding the generic structure and language features of their peers' essays were explored. From the reflection analysis sheets, 172 sentences from the higher English proficiency group and 146 sentences from the lower English proficiency group were analyzed. The results of phase 1 are illustrated in Table 5. As for the result of the generic structure, more learners in the higher English proficiency group than in the lower English proficiency group tended to present data analysis and discussion about their outcomes (higher-level: $n=70$, lower-level: $n=44$ ). Similar results were observed for the reflection on genre purpose (higher-level: $n=8$, lower-level: $n=3$ ). For instance, for the generic structure analysis such as move analysis of the first paragraph for the discussion genre, one learner stated the following:

My partner's structure in the introduction part was in this order: (1) describe the current situation, (2) introduce the essay topic, (3) explain the background issue of the topic, and then finally (4) provide some explanation that played a bridge function for readers to understand what the second and third paragraphs would explain. On

Table 4 Data Collection Dates

\begin{tabular}{|c|c|c|}
\hline & Pre & Post \\
\hline $\begin{array}{l}\text { Pre-non instructional timed writing essay }{ }^{\mathrm{a}} \text { and post-instructional timed writing } \\
\text { essay }\end{array}$ & $\begin{array}{l}\text { September, } \\
2017\end{array}$ & $\begin{array}{l}\text { January, } \\
2018\end{array}$ \\
\hline Self-reflection written texts: Analysis sheet & & $\begin{array}{l}\text { January, } \\
2018\end{array}$ \\
\hline
\end{tabular}

Note. ${ }^{\text {T}}$ The pre-non instructional timed-writing essay task was conducted before the first TLC was introduced in the classroom 
Table 5 Frequency Analysis Results of Learners' Reflection Sheets of the Genre Analysis of Peers' Essays

\begin{tabular}{|c|c|c|c|}
\hline & Criteria & $\begin{array}{l}\text { Higher- } \\
\text { level }\end{array}$ & $\begin{array}{l}\text { Lower- } \\
\text { level }\end{array}$ \\
\hline \multirow{3}{*}{$\begin{array}{l}1 \text { Generic } \\
\text { structure }\end{array}$} & (1) To identify the purpose of the discussion essay & 8 & 3 \\
\hline & $\begin{array}{l}\text { (2) To describe the structure of the target genre: 1) Issue, 2) Argument for, 3) Argument } \\
\text { against, and 4) Conclusion }\end{array}$ & 70 & 44 \\
\hline & Total & $78(46 \%)$ & $\begin{array}{l}47 \\
(32 \%)\end{array}$ \\
\hline \multirow{15}{*}{$\begin{array}{l}2 \\
\text { Lexicogrammar }\end{array}$} & (3) To explain general personal nouns & 2 & 0 \\
\hline & (4) To write about the uses of abstract nouns & 0 & 0 \\
\hline & (5) To write about the uses of action verbs & 0 & 0 \\
\hline & (6) To write about the uses of "verbal verbs" & 0 & 0 \\
\hline & Total & $2(1 \%)$ & $0(0 \%)$ \\
\hline & (7) To write about modalities & 35 & 23 \\
\hline & (8) To write about modality + adverbs & 12 & 23 \\
\hline & $\begin{array}{l}\text { (9) To write these fixed phrases to express the writer's opinion/modality: It is possible } \\
\text { that, I guess that, or It is certain that }\end{array}$ & 3 & 0 \\
\hline & Total & $50(29 \%)$ & $\begin{array}{l}46 \\
(31 \%)\end{array}$ \\
\hline & (10) To explain construct conjunctions and signposts & 14 & 30 \\
\hline & (11) To explain demonstrative pronouns such as that and this & 0 & 0 \\
\hline & (12) To use appropriate thematic ties and referential links to extend genre & 0 & 0 \\
\hline & Total & $14(8 \%)$ & $\begin{array}{l}30 \\
(21 \%)\end{array}$ \\
\hline & Other features & $28(16 \%)$ & $\begin{array}{l}23 \\
(16 \%)\end{array}$ \\
\hline & Sum & 172 & 146 \\
\hline
\end{tabular}

Note. Numbers indicate frequency. The criteria are adapted from Burns et al. (1996) and Nagao (2018). The 12 criteria are the same as those given in Table 2

the other hand, the first paragraph of the introduction part of my essay had the following structure: (1) describe the background information, (2) describe the current situation, (3) introduce the essay topic, and (4) provide some statistical data. Overall, through this move analysis of the first paragraph, I realized that the last sentence of the paragraph with the bridge function made it easier for me to understand the essay. (extracted from the reflection sheet of Student no. 6 from the higher English proficiency group)

In terms of the generic structure analysis, some learners analyzed the second, third, and final paragraphs. An example is given as follows:

In my partner's essay, the content of the second, third, and concluding paragraphs was in the order of (1) argument against, (2) argument for, and (3) argument against. I wrote the same pattern. This pattern is good for readers because readers can compare the arguments given in the second and third paragraphs and then read the content of the final paragraph; in this case, the "argument against" is emphasized. So, I think this pattern of writing can be effective for readers to remember what the writer wanted to say. (extracted from the reflection sheet from Student no. 2 in the lower English proficiency group)

Regarding the results of the lexicogrammatical features for making appropriate ideational meaning (Field), a few learners in the higher English proficiency group analyzed 
the use of personal pronouns, while learners in the lower English proficiency group did not mention the process (verbs). Vocabulary items related to interpersonal meaning were analyzed by a large number of learners in both the higher- and lower-level groups. Learners clearly showed understanding of how to write modalities such as will, can, should, and need to, as well as how to write adverbs such as typically, absolutely, and definitely in their reflection analysis sheets (higher-level: $n=50$, lower-level: $n=46$ ). Appropriate lexicogrammatical features of textual meaning, especially the use of "construct conjunctions" and "signposts," received attention from EFL learners in the lower English proficiency group (higher-level: $n=14$, lower-level: $n=30$ ). For example, Student no. 9 in the lower English proficiency group wrote in an analysis comment, "I think that these signposts, such as In fact and Besides, are persuasive for readers."

\section{Phase 2: pre non-instructional timed writing and post instructional timed writing tasks}

In phase 1, in both the higher and lower English proficiency groups, the data analysis result suggests that many learners illustrated their understanding in their reflection sheets of how to use vocabulary items related to the interpersonal meaning of the target text, especially the use of modal verbs, will, can, should, and need to. In phase 2, the answer to RQ 2 was explored.

In this phase, pre-instructed essays and post-instructed essays were analyzed. The total number of words in the text was counted (higher-level: $n=1433$, lower-level: $n=$ 1017), the total number of sentences (higher-level: $n=105$, lower-level: $n=88$ ), and the frequency of the nine modal auxiliaries in each paragraph of learners' pre- and post-discussion genre texts (see Table 6).

The results show that the frequency of the modal auxiliary, shall, did not change from the pre-writing texts to post-writing texts in either the higher- or lower-level groups. That is to say, no learner used the word shall in either their pre- or post-writing essays. The frequency of the use of must was 2 in the pre-writing texts and 0 in the post-writing texts. The results of these modal auxiliaries, can, will, and should, showed a significant change from pre- to post-writing. The total frequency (both classes) of can in the first and second paragraphs was large in the pre-writing texts, and most appearances of can were in the second and third paragraphs of the post-writing texts. The results show that the frequency of the modal auxiliary will changed dramatically between the pre- and post-writing texts. The frequency was 1 in the first paragraph in the pre-writing texts, but 9 for the post-writing texts in total. A similar change was found in the second paragraph. Finally, the frequency of the modal auxiliary should also changed dramatically, especially in the final paragraph; in the final paragraphs, the frequency was 12 for the post-writing texts but only 3 for the pre-writing texts, and even then, it was only found among higher proficiency learners. No learners in the lower level wrote should in the pre-writing; its use frequency was 1 in the first paragraph, 3 in the second paragraph, 1 in the third paragraph, and 8 in the final paragraph in post-writing texts. To sum up, the post-test results for lower-proficiency learners showed a dramatic increase in the use of the words should and will, which did not appear at all in their pre-writing texts; will was used frequently in the first paragraph of the post-tests, which denotes intention, while should appeared often in the final paragraph. 
Table 6 Frequency Analysis of the Modal Auxiliaries of the Pre-and Post-Genre Essays

\begin{tabular}{|c|c|c|c|c|c|c|c|c|c|c|c|c|c|c|c|c|c|}
\hline & Paragraph & can & & & & & & & & mig & & & & & & & \\
\hline & & Pre & & & & Post & & & & Pre & & & & Post & & & \\
\hline & & 1 & 2 & 3 & 4 & 1 & 2 & 3 & 4 & 1 & 2 & 3 & 4 & 1 & 2 & 3 & 4 \\
\hline Higher & Total & 6 & 10 & 6 & 0 & 3 & 12 & 7 & 4 & 1 & 0 & 2 & 2 & 0 & 0 & 1 & 0 \\
\hline & Mean & 0.7 & 1.1 & 0.7 & 0 & 0.3 & 1.3 & 0.8 & 0.4 & 0 & 0 & 0 & 0 & 0 & 0 & 0.1 & 0 \\
\hline Lower & Total & 7 & 7 & 1 & 0 & 4 & 7 & 9 & 4 & 0 & 0 & 0 & 0 & 0 & 0 & 0 & 0 \\
\hline & Mean & 0.6 & 0.6 & 0.1 & 0 & 0.4 & 0.6 & 0.8 & 0.4 & 0 & 0 & 0 & 0 & 0 & 0 & 0 & 0 \\
\hline & Paragraph & may & & & & & & & & shou & & & & & & & \\
\hline & & Pre & & & & Post & & & & Pre & & & & Post & & & \\
\hline & & 1 & 2 & 3 & 4 & 1 & 2 & 3 & 4 & 1 & 2 & 3 & 4 & 1 & 2 & 3 & 4 \\
\hline Higher & Total & 0 & 0 & 0 & 0 & 0 & 0 & 0 & 1 & 2 & 3 & 2 & 3 & 3 & 3 & 0 & 4 \\
\hline & Mean & 0 & 0 & 0 & 0 & 0 & 0 & 0 & 0.1 & 0 & 0 & 0 & 0 & 0.3 & 0.3 & 0 & 0.4 \\
\hline Lower & Total & 1 & 0 & 0 & 0 & 1 & 3 & 0 & 0 & 0 & 0 & 0 & 0 & 1 & 3 & 1 & 8 \\
\hline & Mean & 0.1 & 0 & 0 & 0 & 0.1 & 0.3 & 0 & 0 & 0 & 0 & 0 & 0 & 0.1 & 0.3 & 0.1 & 0.7 \\
\hline & Paragraph & shal & & & & & & & & wou & & & & & & & \\
\hline & & Pre & & & & Post & & & & Pre & & & & Post & & & \\
\hline & & 1 & 2 & 3 & 4 & 1 & 2 & 3 & 4 & 1 & 2 & 3 & 4 & 1 & 2 & 3 & 4 \\
\hline Higher & Total & 0 & 0 & 0 & 0 & 0 & 0 & 0 & 0 & 0 & 0 & 0 & 0 & 0 & 0 & 0 & 1 \\
\hline & Mean & 0 & 0 & 0 & 0 & 0 & 0 & 0 & 0 & 0 & 0 & 0 & 0 & 0 & 0 & 0 & 0.1 \\
\hline Lower & Total & 0 & 0 & 0 & 0 & 0 & 0 & 0 & 0 & 0 & 0 & 0 & 0 & 0 & 0 & 1 & 0 \\
\hline & Mean & 0 & 0 & 0 & 0 & 0 & 0 & 0 & 0 & 0 & 0 & 0 & 0 & 0 & 0 & 0.1 & 0 \\
\hline & Paragraph & will & & & & & & & & mus & & & & & & & \\
\hline & & Pre & & & & Post & & & & Pre & & & & Post & & & \\
\hline & & 1 & 2 & 3 & 4 & 1 & 2 & 3 & 4 & 1 & 2 & 3 & 4 & 1 & 2 & 3 & 4 \\
\hline Higher & Total & 1 & 2 & 0 & 1 & 4 & 4 & 2 & 6 & 0 & 0 & 0 & 0 & 0 & 0 & 0 & 0 \\
\hline & Mean & 0 & 0 & 0 & 0 & 0.4 & 0.4 & 0.2 & 0.7 & 0 & 0 & 0 & 0 & 0 & 0 & 0 & 0 \\
\hline Lower & Total & 0 & 0 & 0 & 0 & 5 & 6 & 1 & 3 & 2 & 0 & 0 & 0 & 0 & 0 & 0 & 0 \\
\hline & Mean & 0 & 0 & 0 & 0 & 0.5 & 0.5 & 0.1 & 0.3 & 0.2 & 0 & 0 & 0 & 0 & 0 & 0 & 0 \\
\hline & Paragraph & $\mathrm{COU}$ & & & & & & & & & & & & & & & \\
\hline & & Pre & & & & Post & & & & & & & & & & & \\
\hline & & 1 & 2 & 3 & 4 & 1 & 2 & 3 & 4 & & & & & & & & \\
\hline Higher & Total & 1 & 0 & 0 & 0 & 0 & 2 & 2 & 0 & & & & & & & & \\
\hline & Mean & 0 & 0 & 0 & 0 & 0 & 0.2 & 0.2 & 0 & & & & & & & & \\
\hline Lower & Total & 0 & 0 & 0 & 0 & 0 & 1 & 1 & 0 & & & & & & & & \\
\hline & Mean & 0 & 0 & 0 & 0 & 0 & 0.1 & 0.1 & 0 & & & & & & & & \\
\hline
\end{tabular}

To sum up the frequency of the modal verb will in pre-writing tasks, the result shows that $n=1$ in the first paragraph, $n=2$ in the second paragraph, and $\mathrm{n}=1$ in the conclusion of essays from the higher-level group; will was not used in any essay from the lower English proficiency group.

Learners in the higher-level group wrote sentences including the modal verb will in their pre-writing texts. The following is an example from the second paragraph: "[s] ome people think they have the right to privacy because they have to be protected by it. If someone uses their information for crime, their privacy will disappear" (extracted from Student no. 1). The use of will in the above sentence can be interpreted as 
indicating probability. Student No. 6 writes as follows in the first paragraph: "If it had not been for individual privacy many people can know our privacy and it will cause problems"; this use of will reflects the writer's opinion of probability. Finally, the first paragraph of Student no. 8 states, "[t] his essay will discuss both views." This will can be interpreted as an obligation; the writer is supposed to introduce both views on the topic in the discussion genre essay.

Learners in the higher-level group wrote sentences including the modal verb will in their post-writing texts $(n=4$ in the first paragraph, $n=4$ in the second paragraph, $n=$ 2 in the third paragraph, and $n=6$ in the final paragraph). The common feature of the use of will in the first paragraph is that the writers used it to denote "obligation," which was the same result as in the pre-writing texts. In paragraph 2 of the post-writing texts, will appeared with the meanings of probability $(\mathrm{n}=2)$ and obligation $(\mathrm{n}=1)$. For example, Student no. 4 stated the following: "According to [newspaper's name] (2013), they decided that the National Center Test for University Admissions will be banned in the next few years and the new system will be adopted." This meaning of will possibly has a different meaning. Will denoting probability also appeared in both the third $(\mathrm{n}=$ $2)$ and fourth paragraphs $(n=5)$.

The total frequency of can in the first and second paragraphs was large in the pre-writing texts (first paragraph: $n=13$, second paragraph: $n=17$ ), while most appearances of can were in the second and third paragraphs in the post-writing texts. The frequency of must was $\mathrm{n}=2$ in the pre-writing texts but $n=0$ in the post-writing texts, and only among the lower English proficiency group.

\section{Discussion}

Most EFL learners in Japan are told to memorize the literal meanings of vocabulary items without being taught their functional meanings. Thus, many English learners are taught that the word can denotes possibility, and to memorize the phrase be able to as it has the same meaning as can; this can be a typical way to teach. However, teaching writing based on SFL-GBA can provide EFL learners with the opportunity to learn that the word can has the meaning of possibility and also has a degree of value. Thus, when the writer wants to express and control his or her opinions or judgments, s/he can use the word can appropriately to create meaning between the writer and readers without making the first person I explicit (Halliday, 2001). The word must carries the highest probability among other modal verbs, as identified by Halliday (1985). Wang (2014) interpreted that the modal verb will shows the willingness of the writers and is also subjective and implicit.

In phase 1, in-depth, qualitative reflection sheets for genre analysis of peers' essays were used to analyze the students' meaning-making choices, demonstrating how much they understood the target genre text. In terms of understanding the generic structure and genre purpose, more learners with higher, rather than lower, English proficiency tended to show better understanding.

Regarding understanding of the lexicogrammar, lower English proficiency learners showed improvement in understanding some vocabulary items related to interpersonal meaning (Table 5; higher level group $=29 \%$, lower-level group $=31 \%$ ). Improvement in the understanding of modal auxiliaries (interpersonal meaning) in the target genre to examine their improvement of awareness was the focus. Interpersonal meanings are 
expressed by modality (Halliday \& Matthiessen, 2014), and there are links between the language systems and vocabulary choices made by the writer (Eggins, 2004). Choosing an appropriate modal auxiliary in discussion genre texts is related to writers' level of familiarity with their audience and their attitudes and judgments (Eggins, 2004). These features were found in the learners' reflection sheets. According to Student no. 9 of the higher-level group:

The genre analysis comparison data showed that, in my partner's essay, her opinion was against the topic and there was little supporting evidence. Therefore, it was hard for me to understand her (as the writer) opinion. My suggestion is to add some auxiliary verbs such as "can, must, should" in this final paragraph in order to show her strong opinion so that I (as the reader) can understand her opinion clearly.

Finally, in phase 2, to examine learners' proficiency improvement, frequency analysis of the modal auxiliaries in the pre- and post-genre essays was conducted. The results showed that the frequency of the modal auxiliaries can, will, and should changed significantly from pre- to post-writing. The modal verb will is explained as being closely related to the human activity of communication; in particular, will can denote "probability, usuality, obligation, or inclination" (Halliday \& Matthiessen, 2014, p. 186, p. 691). Moreover, the results imply that use of this verb was associated with different meanings. However, it could not be confirmed whether learners used these different meanings of will intentionally.

The total frequency (for both classes) of can in the first and second paragraphs was large in the pre-writing texts, while most appearances of can occurred in the second and third paragraphs in the post-writing texts.

The most remarkable result was the frequency of the modal auxiliary should, particularly in the final paragraph of the lower English proficiency group. In the conclusion paragraph of the discussion genre text, no EFL writer in the lower English proficiency group chose to write should in the pre-writing task; however, should appeared several times in the post-writing texts $(n=8)$.

In phase 1, between the higher and lower English proficiency groups, the data analysis result suggests that many of the learners illustrated their understanding in their reflection sheets of how to use vocabulary items related to the interpersonal meaning of the target text, particularly the use of the modal verbs will, can, should, and need.

The results in phase 2 show that the frequency of use of the modal auxiliary shall in both classes did not change from the pre-writing to post-writing texts; none of the learners wrote the word in either their pre- or post-writing essays. This may be because they did not need to use it or they did not know how to use it, even though they had previously been taught its meaning.

Although no learner in either group used must in the post-writing, must includes a variety of meanings: It reflects the writer's certainty and can denote always, required, or determined. One interpretation of the fact that must, which has a high value, was used less often is that the writer's purpose was possibly not to show the degeneration of the writer's status and power or the writer's uncertainty; rather, the writer may have tried to present their demands and take responsibility (Wang, 2014). This can be considered the learners' understanding of the purpose of the "discussion genre essay," which is to 
present different points of view (especially from both sides: pros and cons and advantages and disadvantages) in order to make an informed decision.

Improving their L2 writing skills can be challenging for EFL learners, because, first, they tend to have difficulties generalizing and organizing ideas using appropriate lexicogrammatical functions and, second, they tend to have little ability to implement such choices into intelligible text (Rajagopalan \& Jie, 2016).

One limitation of this study is the small number of participants; therefore, these results are merely tendencies, and it cannot be concluded that all EFL lower English proficiency learners improved their understanding of generic structure and lexicogrammatical features. However, the SFL-GBA method allowed EFL learners to increase their awareness of text-type in terms of language and text features. This understanding may link with the aspect of how to turn ideas into intelligible text (the discussion genre text). Similarly, the other limitation of this research is that it was not possible to provide a deterministic evaluation of how much the learners precisely understood the different degrees of modal verbs' values and managed to reflect their interpersonal meaning when they chose to use these modal verbs in the post-writing tasks. To solve the above issue, follow-up interviews with the target learners will be necessary in future research.

\section{Conclusion}

This study has investigated the changes in Japanese EFL learners' awareness of language features and generic structures of "discussion genre texts" through the genre-based approach to text-based writing lessons during a 15-week course. This paper has described an SFL activity-based GBA for teaching writing to EFL learners with higher and lower English proficiencies. It found that the GBA paired with a sequenced and well-structured teaching methodology can be an effective teaching methodology in writing lessons. This approach included macro and micro scaffolding to assist learners to organize their writing and understand the nature of the target text in the classroom learning context. The results suggested that teaching EFL learners to write by developing their rhetorical awareness was a challenge in this particular classroom setting.

\section{Abbreviations}

EFL: English as a Foreign/ Second Language; ESL: English as a Second Language; ESOL: English for Speakers of Other Languages; ESP: English for specific purposes; GBA: Genre-based approach; SFL: Systematic functional linguistics; TLC: Teaching-learning cycle

\section{Acknowledgements}

I would like to acknowledge Dr. Peter Mickan (The University of Adelaide). His thoughtful comments and feedback on SFL GBA lesson plans significantly improved the manuscript.

I would like to thank reviewers and editors for their valuable feedback.

\section{Funding}

This research was supported by a Grant-in-Aid for Young Scientists (B) Grant Number JP16K16891 from the Japan Society for the Promotion of Science.

Availability of data and materials

The datasets used and/or analyzed during the current study are available from the corresponding author on reasonable request.

Declarations

Ethics approval, consent to participate, and consent for publication were received from app participants and committee members for this study. 
Authors' contributions

AN designed study, performed the research, analyzed the data and wrote the paper. The author read and approved the final manuscript.

\section{Competing interests}

The author declares that she has no competing interests.

\section{Publisher's Note}

Springer Nature remains neutral with regard to jurisdictional claims in published maps and institutional affiliations.

Received: 30 August 2018 Accepted: 15 April 2019

Published online: 14 May 2019

\section{References}

Badger, R., \& White, G. (2000). A process genre approach to teaching writing. ELT Journal, 54(2), 153-160. https://doi.org/10. 1093/elt/54.2.153.

Benesse Educational Research and Development Institute. (2016). Chyukou no eifgoshidou ni Kansuru jittaichyosa 2015 (in Japanese) [Fact-finding investigation on teaching methodologies in Junior high and senior high schools pedagogy]. Retrieved 21 Apr 2018, from http://berd.benesse.jp/up_images/research/Eigo_Shido_all.pdf

Bernstein, B. (1990). The structuring of pedagogic discourse: Class, codes \& control (Vol. IV). London: Routledge.

Bhatia, V. (2004). Worlds of written discourse: A genre-based view. London: A\&C Black.

Burns, A., Joyce, H., \& Gollin, S. (1996). "I see what you mean": Using spoken discourse in the classroom: A handbook for teachers. Sydney: National Centre for English Language Teaching and Research, Macquarie University Retrieved 21 Apr 2018, from http://www.ameprc.mq.edu.au/docs/research_reports/I_see_what_U_mean.pdf.

Carstens, A. (2009). The effectiveness of genre-based approaches in teaching academic writing: Subject-specific versus cross disciplinary emphases (Doctoral dissertation, University of Pretoria).

Chen, Y. S., \& Su, S. W. (2012). A genre-based approach to teaching EFL summary writing. ELT Journal, 66(2), 184-192. https:// doi.org/10.1093/elt/ccr061.

Cornelius, S., \& Cotsworth, B. (2015). Genre analysis and genre-based approaches to EFL writing: A critical analysis. Kansai University Foreign Languages Pedagogy Forum, 14(3), 15-21 Retrieved April 22, 2019, Retrieved from http://hdl.handle.net/ $10112 / 9575$.

Eggins, S. (2004). An introduction to systemic functional linguistics. London: Pinter.

Fakhruddin, W. F. W. W., \& Hassan, H. (2015). A review of genre approaches within linguistic traditions. LSP International Journal, 2(2), 53-68. https://doi.org/10.11113/lspi.v2n2.28.

Feez, S. (2002). Heritage and innovation in second language education. In A. M. Johns (Ed.), Genre in the classroom: Multiple perspectives (pp. 43-69). Mahwah: Lawrence Erlbaum Associates.

Feez, S. (1998). Text-Based Syllabus Design. Sydney: Macquarie University/AMES.

Halliday, M. A. K., \& Hasan, R. (1989). Language, context, and text: Aspects of language in a social-semiotic perspective (2nd ed.) Oxford: Oxford University.

Halliday, M. A. K. (1975). Learning how to mean: Explorations in the development of language. London: Edward Arnold.

Halliday, M. A. K. (1978). Language as social semiotic. London: Edward Arnold.

Halliday, M. A. K. (1989). Spoken and written language. Oxford: Oxford University Press.

Halliday, M. A. K. (2001). Towards a theory of good translation. In E. Steiner \& C. Yallop (Eds.), Exploring translation and multilingual text production: Beyond content (pp. 13-18). Berlin \& New York: Mouton de Gruyter.

Halliday, M.A.K., \& Matthiessen, C. M. I. M. (2014). An introduction to functional grammar. Oxon \& New York: Routledge.

Hammond, J., Burns, A., Joyce, H., Brosnan, D., Gerot, L., Solomon, N., \& Hood, S. (1992). English for social purposes: A handbook for teachers of adult literacy. Sydney: National Centre for English Language Teaching and Research, Macquarie University.

Martin, J. R. (1984). Language, register and genre. In F. Christie (Ed.), Children writing: Reader (pp. 21-29). Geelong: Deakin University Press.

Martin, J. R. (1999). Mentoring semogenesis: "Genre-based" literacy pedagogy. In F. Christie (Ed.), Pedagogy and the shaping of consciousness: Linguistic and social processes (pp. 123-155). London: Cassell.

Martin, J. R., \& Rose, D. (2008). Genre relations: Mapping culture. London/Oakville: Equinox Publishing Ltd.

Martin, J. R., \& White, P. R. (2005). The language of evaluation (Vol. 2). Basingstoke: Palgrave Macmillan.

Murakoshi, R. (2015). Nihonjin koukousei eigogakushiyushixya no eisakubbun nimiru bunhoutokuseino hattatsu. [The development of grammatical features in English compositions of Japanese high school students]. ARCLE Review, 9(3), 1726 Retrieved 31 Jan 2019, from http://www.arcle.jp/research/books/data/html/data/pdf/vol9_3-2.pdf.

Nagao, A. (2017). Longitudinal study of EFL students using the systemic functional linguistics method. International Education Studies, 10(11), 47-62. https://doi.org/10.5539/ies.v10n11p47

Nagao, A. (2018). A genre-based approach to writing instruction in EFL classroom contexts. English Language Teaching, 11(5), 130-147. https://doi.org/10.5539/elt.v11n5p130.

NSW Department of School Education. (1989). The discussion genre: Language and social power. Disadvantaged schools' program. Sydney: Metropolitan East region, NSW Department of Education.

Rajagopalan, U. M., \& Jie, S. (2016). Adopting a SFL-oriented approach for evaluating genre-based academic abstracts of EST undergraduate students in Japan. In 2016 international conference on advanced mechatronic systems (ICAMechS) (pp. 510515). https://doi.org/10.1109/ICAMechS.2016.7813501.

Rose, D. (2008). Writing as linguistic mastery: The development of genre-based literacy pedagogy. In D. Myhill, D. Beard, M. Nystrand, \& J. Riley (Eds.), Handbook of writing development (pp. 151-166). London: Sage.

Rose, D. (2013). Genre in the Sydney school. In J. Gee \& M. Handford (Eds.), The Routledge handbook of discourse analysis (pp. 209-225). London: Routledge. 
Shi, L. S. (2015). Chinese EFL teachers' cognition about the potential of SFL genre-based pedagogy for teaching College English writing: A case study at a university in China (Doctoral dissertation), Faculty of Social Sciences, University of Wollongong. http://ro.uow.edu.au/theses/4722

Srinon, U. (2011). A longitudinal study of developments in the academic writing of Thai University students in the context of a genre based pedagogy (Doctoral dissertation). Retrieved 23 Apr 2019, from the University of Adelaide database https:// digital.library.adelaide.edu.au/dspace/bitstream/2440/70282/8/02whole.pdf .

Sugiura, R. (2017). English language learning of Japanese university students: A qualitative investigation based on narrative frames. Journal of Higher Education, Tokai University (Hokkaido Campus), 16(3), 1-14 Retrieved April 23, 2019, from http:// www.jhe.u-tokai.ac.jp/jhe16_1.pdf .

Swales, J. (1990). Genre analysis: English in academic and research settings. Cambridge: Cambridge University Press.

Syarifah, E. F., \& Gunawan, W. (2015). Scaffolding in the teaching of writing discussion texts based on SFL genre-based approach. English Review: Journal of English Education, 4(1), 39-53. https://doi.org/10.25134/erjee.v4i1.306.

Tatsuki, M. (Ed.). (2006). Kotoba wa ikiteiru: The introduction of systemic functional linguistics [in Japanese]. Tokyo: Kuroshio Publishers.

Thomson, E., de Silva Joyce, H., \& Sano, M. (2017). Mapping genres, mapping culture: Japanese texts in context. Amsterdam: John Benjamins Publishing Company.

Tsou, W., \& Lin, V. (2013). The effects of genre-based writing instruction on college English academic literacy. Bulletin of Educational Research, 59(2), 115-151. https://doi.org/10.3966/102887082013065902004.

Viriya, C., \& Wasanasomsithi, P. (2017). The effect of the genre awareness approach on development of writing ability. International Forum of Teaching and Studies, 13(1), 11-22 Retrieved 23 Apr 2019, from http://scholarspress.us/journals/ IFST/pdf/IFOTS-1-2017/IFOTS-v13n1-art2.pdf .

Wang, X. (2014). The mood and modality in the bible: A systemic functional perspective. Theory and Practice in Language Studies, 4(2), 255-261. https://doi.org/10.4304/tpls.4.2.255-261

Watanabe, H. (2016). Genre analysis of writing tasks in Japanese university entrance examinations. Language Testing in Asia, 6(1), 4. https://doi.org/10.1186/s40468-016-0026-8.

Yamashita, S. T. (2012). Japanese pharmaceutical students' attitudes toward English learning: Survey results from one university [in Japanese]. Bulletin of Osaka University of Pharmaceutical Sciences, 6(2), 41-47 Retrieved 23 Apr 2019 from https://www.oups.ac.jp/gakujutsu/kiyo/vol6/web/web_06_Smith.pdf .

Yasuda, S. (2012). The implementation of genre-based tasks in foreign language writing instruction: A longitudinal study of writers' rhetorical awareness, writing quality, and lexicogrammatical choices (Doctoral dissertation). Retrieved 21 Apr 2018 , from the University of Hawaii at Manoa database http://hdl.handle.net/10125/101043 .

Yasuda, S. (2015). Exploring changes in FL writers' meaning-making choices in summary writing: A systemic functional approach. Journal of Second Language Writing, 27(3), 105-121. https://doi.org/10.1016/j.jslw.2014.09.008.

\section{Submit your manuscript to a SpringerOpen ${ }^{\circ}$ journal and benefit from:}

- Convenient online submission

- Rigorous peer review

- Open access: articles freely available online

- High visibility within the field

- Retaining the copyright to your article

Submit your next manuscript at $\boldsymbol{s p r i n g e r o p e n . c o m ~}$ 